\title{
Correlation of degree of left ventricular volume overload with clinical course in aortic and mitral regurgitation ${ }^{1}$
}

\author{
Michael J. Tyrrell ${ }^{2}$, R. Curtis Ellison, Paul G. Hugenholtz ${ }^{3}$, and \\ Alexander S. Nadas \\ From the Sharon Cardiovascular Unit of the Children's Hospital Medical Center and the \\ Department of Pediatrics, Harvard Medical School, Boston, Massachusetts, U.S.A.
}

The results of left ventricular volume studies using biplane angiocardiography are described in 20 patients with mitral regurgitation and in 27 patients with aortic regurgitation. In both lesions, $a$ regurgitant fraction of over 60 per cent was likely to be associated with severe symptoms and most patients in this group required operation. End-diastolic volumes were higher in patients with aortic regurgitation and were tolerated with fewer symptoms than in the group with mitral regurgitation. Most $(19 / 2 I)$ of the patients with low ejection fractions $(<0.60)$ had either rheumatic valvular lesions or had had potassium citrate as a cardioplegic drug at previous heart operations. The possible myocardial effects of these factors are discussed.

Left ventricular volume studies have proved useful in the assessment of valvular regurgitation by quantitating regurgitant flow and giving a measure of the relative importance of valvular and myocardial disease.

Determination of left ventricular volumes during systole and diastole has made it possible to measure the amount of regurgitant flow in lesions with valvular insufficiency (Sandler et al., 1963). The possibility that this assessment may aid in the management of patients with aortic and mitral regurgitation by separating out those who have myocardial dysfunction in addition to their valve lesion led us to relate the volume parameters to the clinical findings and course in a group of 47 children and young adults with these lesions.

While in chronic regurgitant lesions the augmented demand for ejected volume is primarily compensated for by increased preloading of the ventricle, i.e. a larger enddiastolic volume (Hugenholtz and Wagner, 1970), in acutely induced regurgitant lesions it has been observed that suddenly reduced

Received 12 January 1970.

1 Supported in part by grants HE 5310-10 and HE 10436-03 from the National Heart Institute of the National Institutes of Health, Bethesda, Md., U.S.A.

2 Present address: Department of Cardiology, Hospital for Sick Children, Toronto, Canada.

3 This study was done during the tenure of an Established Investigatorship of the American Heart Association. Present address: Department of Cardiology, University Hospital, Rotterdam, The Netherlands. afterload may lead to a higher than normal ejection fraction (Urschel et al., 1968), without the need for cardiac dilatation. Hence, this study was further designed to determine if a 'normal' ejection fraction might be associated with clinical symptoms indicative of congestive heart failure.

\section{Subjects and methods}

There were 20 female and 27 male patients: 27 patients had aortic regurgitation, with a mean age of 17.8 years (range 5-44 years), and 20 patients had mitral regurgitation, with a mean age of 15.4 years (range 4-43 years); 23 patients had rheumatic lesions, 24 patients had congenital lesions. Of the 18 patients with congenital aortic regurgitation, there was associated significant aortic stenosis in 2, and there had been previous operations for aortic stenosis in 9 .

All the data were obtained during diagnostic cardiac catheterization using methods previously described from this institution (Hugenholtz and Wagner, 1970). Biplane left ventricular angiocardiograms were taken at 6 or 12 frames per second. Methylglucamine diatrizoate was injected as the contrast medium in a dose of approximately I ml./kg. The first few cardiac cycles after the injection of contrast were analysed in order to avoid alterations in contraction secondary to the haemodynamic effects of the contrast medium. 
When premature or irregular activation occurred, no films were used unless at least 2 normal cycles separated the beat from the extrasystole. In most cases, the measurements of 3 films in end-diastole and 3 in end-systole were averaged. Ventricular volumes were calculated by the area length method of Dodge et al. (1960). The total stroke volume (TSV) was derived from the difference between end-diastolic (EDV) and end-systolic volumes (ESV), and this volume was compared with the forward stroke volume (FSV) measured by the Fick method or by dye dilution technique shortly before the angiocardiogram. The regurgitant fraction (RF) could then be estimated as (TSV-FSV)/TSV. The ejection fraction (EF), i.e. that fraction of the end-diastolic volume expelled during a left ventricular contraction, re- gardless of direction, was calculated as the fraction TSV/EDV. In all patients except 2, the heart rates at the time of the Fick cardiac output measurement and at the time of the angiogram differed by less than 20 per cent of the lower rate; in 26 of the patients the difference was less than Io per cent. The left ventricular mass (LV mass) was calculated by the method of Rackley et al. (1964) assuming the specific gravity of cardiac muscle to be $\mathrm{I} \cdot 05$.

Ranges of normal values obtained previously in this laboratory for EDV are 50 to $80 \mathrm{ml} / \mathrm{m}$. ${ }^{2}$, for LV mass $50-90 \mathrm{~g} . / \mathrm{m}^{2}$, and for EF 0.60 to 0.75 . Kennedy et al. (1966), also using the area length method, found similar normal values: $\mathrm{EDV}=$ $70 \pm 20 \mathrm{ml} . / \mathrm{m}^{2}$, LV mass $=92 \pm 16 \mathrm{~g} . / \mathrm{m} .{ }^{2}$, and $\mathrm{EF}=0.67 \pm 0.08$

TABLE I Data in patients with mitral regurgitation

\begin{tabular}{|c|c|c|c|c|c|c|c|c|c|c|c|c|}
\hline $\begin{array}{l}\text { Case } \\
\text { No. }\end{array}$ & $\begin{array}{l}\text { Age } \\
(y r .)\end{array}$ & Sex & Diagnosis & $\begin{array}{l}\text { Blood } \\
\text { pressure } \\
(\mathrm{mm} . \mathrm{Hg})\end{array}$ & $\begin{array}{l}\text { Left } \\
\text { atrial } \\
\text { size on } \\
x \text {-ray }\end{array}$ & $\begin{array}{l}\text { Systemic } \\
\text { resistance } \\
\text { index } \\
\left(\mathrm{mm} . / \mathrm{l} . / \mathrm{m} .^{2}\right)\end{array}$ & $\begin{array}{l}\text { End-diastolic } \\
\text { vol. } \\
\left(\mathrm{ml} . / \mathrm{m}^{2}\right)\end{array}$ & $\begin{array}{l}\text { Ejection } \\
\text { fraction }\end{array}$ & $\begin{array}{l}L V \\
\operatorname{mass} \\
\left(g \cdot / m \cdot^{2}\right)\end{array}$ & $\begin{array}{l}\text { Regurgitant } \\
\text { fraction }\end{array}$ & $\begin{array}{l}\text { NYH } \\
\text { class a } \\
\text { time } \\
\text { of } \\
\text { study }\end{array}$ & \\
\hline $\mathbf{I}$ & Io & F & $\begin{array}{l}\text { Congenital } \\
\text { (Marfan's) }\end{array}$ & $115 / 75$ & 0 & 25 & 97 & 0.76 & 108 & 0.43 & I & Remains well \\
\hline 2 & 12 & $\mathrm{~F}$ & Congenital & $106 / 70$ & + & 19 & 80 & 0.66 & 70 & 0.04 & I & Remains well \\
\hline 3 & 4 & $M$ & Congenital & $104 / 70$ & + & 14 & 172 & 0.52 & 108 & 0.50 & $\mathbf{I}$ & $\begin{array}{l}\text { Mild fatigue and } \\
\text { dyspnoea have } \\
\text { developed }\end{array}$ \\
\hline 4 & I0 & $\mathbf{F}$ & Rheumatic & $130 / 95$ & 0 & 17 & 125 & 0.68 & 114 & 0.40 & I & Remains well \\
\hline 5 & 12 & $\mathbf{M}$ & Congenital & $110 / 70$ & 0 & 16 & 98 & 0.83 & 54 & 0.27 & I & Remains well \\
\hline 6 & 8 & $\mathbf{M}$ & Congenital & $120 / 70$ & 0 & 9 & II2 & 0.80 & 88 & 0.11 & I & Remains well \\
\hline 7 & I4 & $\mathbf{M}$ & Rheumatic & $130 / 60$ & 0 & 13 & 88 & 0.79 & 82 & 0.09 & II & Stable \\
\hline 8 & 4 & $\mathbf{M}$ & Rheumatic & $105 / 70$ & ++ & 15 & 78 & 0.74 & 72 & 0.17 & II & Stable \\
\hline 9 & II & F & $\begin{array}{l}\text { Congenital } \\
\text { (endocardial } \\
\text { cushion } \\
\text { defect, } \\
\text { post-op.) }\end{array}$ & $110 / 80$ & + & - & II9 & 0.53 & 76 & 0.08 & II & Stable \\
\hline 10 & 13 & $\mathbf{F}$ & Rheumatic & $120 / 50$ & + & 29 & I57 & 0.53 & I7I & 0.60 & II & Doing fairly well \\
\hline I I & 28 & F & Rheumatic & $100 / 70$ & + & 50 & 135 & 0.57 & 85 & 0.60 & III & $\begin{array}{l}\text { Symptoms pro- } \\
\text { gressed; surgery } \\
\text { planned }\end{array}$ \\
\hline 12 & $4 \mathrm{I}$ & $\mathbf{M}$ & Rheumatic & $120 / 80$ & ++ & 47 & 112 & 0.74 & II6 & 0.74 & III & $\begin{array}{l}\text { Valve replacement; } \\
\text { died of aspergillus } \\
\text { endocarditis }\end{array}$ \\
\hline 13 & 17 & F & Rheumatic & $110 / 80$ & ++ & 38 & $15 \mathrm{I}$ & 0.48 & 157 & 0.65 & III & $\begin{array}{l}\text { Valve replacement; } \\
\text { doing well }\end{array}$ \\
\hline 14 & 7 & $\mathbf{M}$ & Rheumatic & $102 / 70$ & $++t$ & 19 & 203 & - & 138 & - & III & $\begin{array}{l}\text { Died of probable } \\
\text { quinidine } \\
\text { sensitivity }\end{array}$ \\
\hline 15 & 22 & $\mathbf{F}$ & Rheumatic & $120 / 60$ & $+t+$ & 28 & 125 & 0.34 & 127 & $0.4 \mathrm{I}$ & III & $\begin{array}{l}\text { Valve replacement; } \\
\text { doing well }\end{array}$ \\
\hline 16 & 9 & $\mathbf{F}$ & $\begin{array}{l}\text { Rheumatic } \\
\text { (associated } \\
\text { const. } \\
\text { pericarditis) }\end{array}$ & $106 / 64$ & +++ & 35 & 133 & 0.50 & 90 & 0.75 & IV & $\begin{array}{l}\text { Valve replacement; } \\
\text { doing well }\end{array}$ \\
\hline I7 & 43 & $\mathbf{M}$ & $\begin{array}{l}\text { Rheumatic } \\
\text { (some MS) }\end{array}$ & $130 / 70$ & + & 30 & 97 & 0.48 & 106 & 0.30 & IV & $\begin{array}{l}\text { Valve replacement; } \\
\text { doing well }\end{array}$ \\
\hline 18 & 21 & $\mathbf{M}$ & Rheumatic & $110 / 80$ & + & $4 I$ & 172 & 0.58 & 152 & 0.85 & IV & $\begin{array}{l}\text { Valve replacement; } \\
\text { doing well }\end{array}$ \\
\hline 19 & 13 & $\mathbf{M}$ & Rheumatic & $94 / 70$ & ++ & 19 & 226 & 0.39 & 149 & 0.66 & IV & $\begin{array}{l}\text { Valve replacement; } \\
\text { died ist post-op. } \\
\text { day, atelectasis }\end{array}$ \\
\hline 20 & I4 & $\mathbf{F}$ & Rheumatic & $87 / 65$ & +++ & 28 & 115 & 0.43 & IIO & 0.33 & IV & $\begin{array}{l}\text { Valve replacement; } \\
\text { doing well }\end{array}$ \\
\hline
\end{tabular}

^ New York Heart Association classification. 
Left atrial size in the group with mitral regurgitation was graded simply as mild, moderate, considerable, and gross by the appearance of the chest radiograph or fluoroscopy with barium swallow. The degree of cardiac enlargement from the chest radiograph was expressed as the cardiothoracic ratio. Both determinations were compared with the measurement of end-diastolic volume. The clinical records were reviewed and symptoms were graded according to the New York Heart Association's classification into functional Classes I-IV. Volume measurements were then related to clinical classifications. The regurgitant fraction in aortic regurgitation was also compared to the pulse pressure.

\section{Results}

Regurgitant fraction The regurgitant fraction ranged from trivial ( $<10 \%$ ) to severe $(>80 \%)$ in both groups. This parameter and the other data for each patient are listed in Tables I and 2. In mitral regurgitation, all patients with a regurgitant fraction over 60 per cent were severely symptomatic (Class III or IV), with one exception who was in Class II (Fig. I). None of those with a regurgitant fraction less than 30 per cent was symptomatic and none required operation. In the range of 30 to 60 per cent, there were some

TABLE 2 Data in patients with aortic regurgitation

\begin{tabular}{|c|c|c|c|c|c|c|c|c|c|c|c|}
\hline $\begin{array}{l}\text { Case } \\
\text { No. }\end{array}$ & $\begin{array}{l}\text { Age } \\
(y r .)\end{array}$ & Sex & Diagnosis & $\begin{array}{l}\text { Blood } \\
\text { pressure } \\
\text { (mm.Hg) }\end{array}$ & $\begin{array}{l}\text { Systemic } \\
\text { resistance } \\
\text { index } \\
\left(\mathrm{mm} . / \mathrm{l} . / \mathrm{m} .^{2}\right)\end{array}$ & $\begin{array}{l}\text { End-diastolic } \\
\text { vol. } \\
\left(m l . / m .^{2}\right)\end{array}$ & $\begin{array}{l}\text { Ejection } \\
\text { fraction }\end{array}$ & $\begin{array}{l}L V \\
\operatorname{mass} \\
\left(g \cdot / m \cdot^{2}\right)\end{array}$ & $\begin{array}{l}\text { Regurgitant } \\
\text { fraction }\end{array}$ & $\begin{array}{l}\text { NYH } \\
\text { class } \\
\text { at } \\
\text { time } \\
\text { of } \\
\text { study }\end{array}$ & \\
\hline $\mathbf{I}$ & 9 & $\mathbf{M}$ & Hurler's syndrome & $150 / 68$ & 23 & 76 & 0.70 & 133 & 0.55 & I & Death from accident \\
\hline 2 & 26 & $\mathbf{M}$ & Rheumatic & $156 / 30$ & 14 & 422 & 0.59 & 468 & 0.86 & I & Died suddenly \\
\hline 3 & II & $\mathbf{M}$ & $\begin{array}{l}\text { Congenital (post-op. } \\
\text { AS) }\end{array}$ & $115 / 70$ & 21 & 132 & 0.81 & 220 & 0.52 & $\mathbf{I}$ & $\begin{array}{l}\text { Slight angina } \\
\text { developed }\end{array}$ \\
\hline 4 & 28 & $\mathbf{M}$ & Rheumatic & $160 / 60$ & 17 & 198 & 0.58 & I8I & 0.50 & I & Remains well \\
\hline 5 & 43 & $\mathbf{M}$ & Rheumatic & $130 / 40$ & 19 & 165 & 0.49 & 210 & 0.47 & I & Remains well \\
\hline 6 & II & $\mathbf{M}$ & $\begin{array}{l}\text { Congenital (post-op. } \\
\text { AS) }\end{array}$ & $110 / 60$ & 12 & 135 & 0.46 & 146 & 0.23 & $\mathbf{I}$ & Remains well \\
\hline 7 & 19 & $\mathbf{F}$ & Congenital & $125 / 80$ & 15 & 9I & 0.66 & 94 & 0.29 & I & Remains well \\
\hline 8 & 17 & $\mathbf{M}$ & $\begin{array}{l}\text { Congenital (post-op. } \\
\text { AS) }\end{array}$ & $150 / 50$ & 24 & III & 0.85 & - & 0.54 & I & Remains well \\
\hline 9 & 12 & $\mathbf{F}$ & $\begin{array}{l}\text { Congenital (post-op. } \\
\text { AS) }\end{array}$ & $100 / 65$ & 17 & IIO & 0.82 & - & 0.04 & I & Remains well \\
\hline 10 & 5 & $\mathbf{M}$ & Congenital & & 15 & $8 I$ & 0.64 & 83 & 0.13 & I & Remains well \\
\hline II & 6 & $\mathbf{M}$ & Hurler's syndrome & $128 / 74$ & 15 & 92 & 0.57 & 102 & 0.43 & I & Remains well \\
\hline 12 & 8 & $\mathbf{M}$ & Rheumatic & $152 / 60$ & 19 & 70 & 0.79 & I2I & 0.13 & I & Remains well \\
\hline 13 & 18 & $\mathbf{M}$ & $\begin{array}{l}\text { Congenital (post-op. } \\
\text { AS) }\end{array}$ & $120 / 40$ & 17 & 145 & 0.52 & 187 & 0.22 & I & Remains well \\
\hline 14 & I7 & $\mathbf{F}$ & Post-op. VSD repair & $129 / 60$ & 22 & 180 & 0.65 & 192 & 0.55 & I & Remains well \\
\hline 15 & 14 & $\mathbf{M}$ & $\begin{array}{l}\text { Congenital (post-op. } \\
\text { coarctation) }\end{array}$ & $142 / 65$ & 19 & 128 & 0.64 & 205 & 0.38 & II & Symptoms lessened \\
\hline 16 & 6 & $\mathbf{F}$ & $\begin{array}{l}\text { Congenital (post-op. } \\
\text { AS) }\end{array}$ & $130 / 58$ & 25 & 138 & 0.46 & 127 & 0.23 & II & Stable \\
\hline 17 & 6 & $\mathrm{~F}$ & Congenital & $122 / 78$ & 12 & 165 & 0.68 & II4 & 0.52 & II & Stable \\
\hline 18 & 8 & $\mathbf{M}$ & $\begin{array}{l}\text { Congenital (post-op. } \\
\text { AS) }\end{array}$ & $100 / 0$ & 15 & IOI & 0.70 & 138 & 0.43 & II & Symptoms lessened \\
\hline 19 & 45 & $\mathbf{F}$ & Rheumatic & $150 / 50$ & 13 & 145 & 0.43 & I7I & 0.13 & II & Stable \\
\hline 20 & II & $\mathbf{M}$ & Congenital & $110 / 76$ & 18 & II4 & - & - & - & II & Stable \\
\hline $2 \mathbf{I}$ & II & $\mathbf{F}$ & Congenital (SBE) & $128 / 30$ & - & II3 & - & I57 & - & III & $\begin{array}{l}\text { Valve replacement; } \\
\text { doing well }\end{array}$ \\
\hline 22 & 16 & $\mathbf{M}$ & $\begin{array}{l}\text { Congenital (post-op. } \\
\text { AS) }\end{array}$ & $140 / 30$ & 13 & 280 & 0.58 & 353 & 0.57 & $\begin{array}{l}\text { Vari- } \\
\text { able } \\
\text { I-III }\end{array}$ & $\begin{array}{l}\text { Valve replacement; } \\
\text { doing well }\end{array}$ \\
\hline 23 & 28 & $\mathbf{M}$ & $\begin{array}{l}\text { Congenital (post-op. } \\
\text { AS) }\end{array}$ & $110 / 60$ & 18 & 136 & 0.76 & 379 & 0.54 & III & $\begin{array}{l}\text { Valve replacement; } \\
\text { doing well }\end{array}$ \\
\hline 24 & 25 & $\mathbf{F}$ & Rheumatic & $120 / 50$ & 25 & 170 & 0.54 & 126 & 0.59 & III & $\begin{array}{l}\text { Valve replacement; } \\
\text { doing well }\end{array}$ \\
\hline 25 & I4 & $\mathbf{F}$ & Rheumatic & $150 / 50$ & 20 & 179 & 0.67 & 217 & - & III & $\begin{array}{l}\text { Valve replacement; } \\
\text { died of septicaemia }\end{array}$ \\
\hline 26 & 25 & $\mathbf{M}$ & Rheumatic & $130 / 60$ & 22 & 175 & 0.66 & 346 & 0.59 & III & $\begin{array}{l}\text { Valve replacement; } \\
\text { doing well }\end{array}$ \\
\hline 27 & 44 & $\mathbf{M}$ & $\begin{array}{l}\text { Rheumatic } \\
\quad \text { (associated MS) }\end{array}$ & $126 / 84$ & 49 & 133 & 0.53 & 107 & 0.64 & IV & $\begin{array}{l}\text { Valve replacement } \\
\text { and mitral comis- } \\
\text { surotomy; doing } \\
\text { well }\end{array}$ \\
\hline
\end{tabular}

\footnotetext{
* New York Heart Association classification.
} 


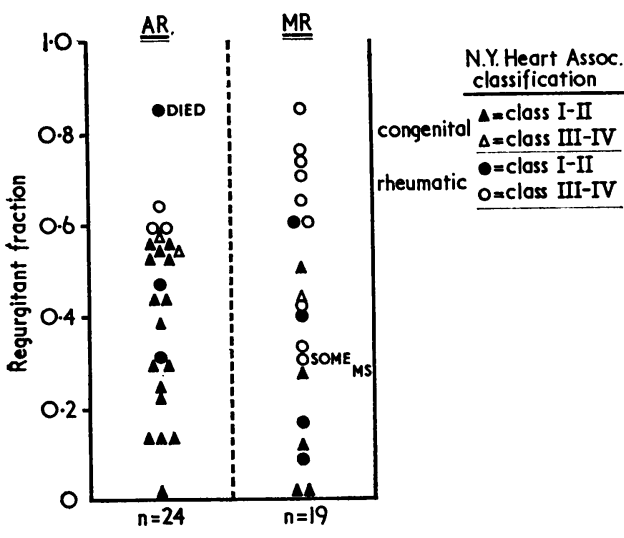

FIG. I The regurgitant fraction for 24 patients with aortic regurgitation and 19 patients with mitral regurgitation. The more symptomatic patients (Class III-IV) are indicated by the open triangles and circles.

without symptoms, but 3 of the 7 were symptomatic enough to require corrective operations.

A comparison was made between the degree of left atrial enlargement and the regurgitant fraction in the mitral regurgitant group. Though most of the patients with a regurgitant fraction over 60 per cent had appreciable left atrial dilatation, while none of the patients with a regurgitant fraction under 30 per cent did so, there was not a good predictive value to the degree of regurgitation from the size of the left atrium.

In the aortic regurgitant group, the regurgitant fraction was closely related to severity of symptoms (Fig. I). All except one of the 5 patients with values over 57 per cent had severe symptoms (Class III to IV). All had aortic valve replacements, except one symptom-free patient with a regurgitant fraction of 86 per cent who died suddenly while an operation was being arranged. One patient with a regurgitant fraction of only 54 per cent also required operation because of severe angina and dyspnoea but had significant aortic stenosis as well. None of the patients with a regurgitant fraction under 50 per cent was operated upon and none had severe symptoms.

The peripheral resistance is another factor that may influence the amount of regurgitation in both aortic and mitral regurgitation. The systemic resistance index was compared with the regurgitant fraction in both groups and, though there was no direct relation, the 5 highest values for systemic resistance index (over 35 units) in the mitral regurgitation group were found in patients with a regurgi- tant fraction over 60 per cent and severe symptoms. In the aortic regurgitant group, the systemic resistance index levels were lower, only 2 patients having values over 25 units. Five of the patients who were in functional Classes III-IV had normal values for systemic resistance index.

In the aortic regurgitation group, a poor correlation $(r=0.25)$ was found between the peripheral pulse pressure taken by cuff in the arm and the regurgitant fraction.

Total ejection fraction The ejection fraction was considered as a first order approximation of myocardial function. In the mitral regurgitation group, 8 patients in functional Classes III-IV (all of whom eventually required valve replacement) had an ejection fraction of under 0.58 (range of 0.34 to 0.58 ) (Fig. 2).

Three others with an ejection fraction below 0.58 had moderate symptoms and were in functional Class II. All 6 patients with a fraction below 0.50 had rheumatic mitral regurgitation.

In the group with aortic regurgitation, there was no clear relation between the ejection fraction and the severity of the symptomatology. The ejection fraction in the severely symptomatic cases ranged from 0.53 to 0.76 . Of the patients with an ejection fraction of 0.55 or less, 4 had rheumatic aortic valve disease and 3 had congenital aortic valve disease. Of the latter, 2 had been given potassium citrate as a cardioplegic drug during previous operation for aortic stenosis. All are free from symptoms at present. Two other patients in this group, also with potassium citrate arrests, had ejection fractions of 0.58 and 0.82 . It seems, therefore, that use of this drug, now out of com-

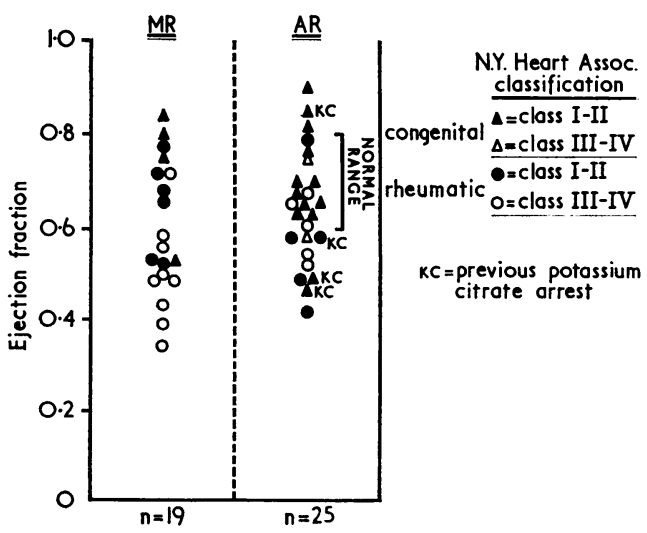

FIG. 2 The total ejection fraction for the two groups of patients. The normal range is approximately 0.6 to 0.8 . 
mon usage, may but does not always result in a low ejection fraction.

End-diastolic volume The end-diastolic volume reflects both the load placed on the heart from the regurgitant lesion and that from a decrease in ejection fraction, indicating myocardial dysfunction. Values for enddiastolic volume ranged from 70 to $422 \mathrm{ml} . / \mathrm{m}^{2}$ (mean $153 \mathrm{ml} . / \mathrm{m}^{2}$ ) in the aortic regurgitation group, and in the mitral regurgitation group from 78 to $226 \mathrm{ml} . / \mathrm{m}^{2}$ (mean $130 \mathrm{ml} . / \mathrm{m}^{2}$ ). The larger volumes in aortic regurgitation were associated with relatively fewer symptoms than comparable end-diastolic volumes in mitral regurgitation (Fig. 3).

When the clinical symptomatology was related to the end-diastolic volume (Tables I and II) a general tendency was noted for patients in Classes I and II to show volumes below $120 \mathrm{ml} . / \mathrm{m}^{2}$ (18 of 29 patients in Classes I, II), while volumes in excess of $120 \mathrm{ml} . / \mathrm{m} .^{2}$ were found in a large percentage (13 of 17 ) of patients with severe symptoms (Classes III, IV). In fact, there were no patients in Class III or IV with normal volumes. The opposite was noted, however, as 8 patients (I with mitral regurgitation and 7 with aortic regurgitation) were found to have large volumes in excess of $120 \mathrm{ml} . / \mathrm{m}^{2}$ without significant symptomatology.

When the chest radiograph was compared with the end-diastolic volume, patients with obvious cardiac enlargement by $x$-ray were shown to have increased end-diastolic volumes while the patients with a normal cardiac silhouette had normal or minimally raised end-diastolic volumes. However, in those patients with slight to moderate cardiac en-

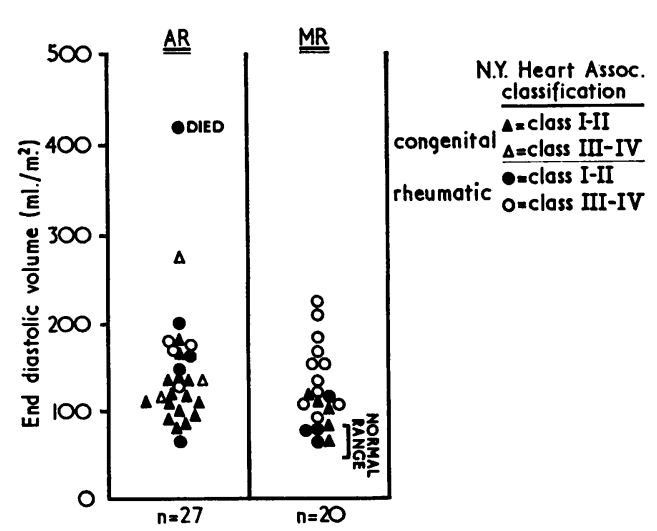

FIG. 3 End-diastolic volume in 27 patients with aortic regurgitation and 20 patients with mitral regurgitation. The normal range is approximately 50 to $80 \mathrm{ml} . / \mathrm{m}^{2}$ largement by radiograph, where the problem of assessment by purely clinical means is most likely to arise, there was no clear relation between the 2 measurements. In fact, patients with only slight cardiac enlargement by chest $x$-ray had end-diastolic volumes as high as $180 \mathrm{ml} . / \mathrm{m}^{2}$, while some with moderately severe cardiac enlargement by chest $x$-ray had little increase in end-diastolic volumes (II5 to $133 \mathrm{ml} . / \mathrm{m}^{2}$ ).

Left ventricular mass The left ventricular mass varied from 54 to $170 \mathrm{~g} . / \mathrm{m}^{2}{ }^{2}$ (mean $109 \mathrm{~g} . / \mathrm{m} .^{2}$ ) in the mitral regurgitation group and from 80 to $467 \mathrm{~g} . / \mathrm{m}^{2}{ }^{2}$ (mean I9I g. $/ \mathrm{m}^{2}{ }^{2}$ ) in the aortic regurgitation group. That a ventricle that delivers increased volume work becomes hypertrophied is shown by plotting end-diastolic volume versus left ventricular mass (Fig. 4). The 2 groups of patients can be separated as there is a relatively greater increase in left ventricular mass per unit increase in end-diastolic volume in the aortic regurgitation patients than there is in those with mitral regurgitation. Two patients with coexistent significant aortic stenosis stand even further out from the rest of the aortic regurgitation group in that they have much greater left ventricular mass in relation to their end-diastolic volumes.

Clinical course Of the 20 patients with mitral regurgitation, 8 had mitral valve replacement with various types of prosthetic valves and 2 of these died in the post-operative period. One patient, a boy aged ro years with a large end-diastolic volume of 225



FIG. 4 End-diastolic volume plotted against left ventricular muscle mass. There was a linear relation between the volume and mass for both groups of patients, but the mass was proportionately greater per unit increase in end-diastolic volume for the patients with aortic regurgitation. 
$\mathrm{ml} . / \mathrm{m}^{2}$ and reduced ejection fraction of 0.39 , died on the day after operation following collapse of a lung. The other death was due to aspergillus endocarditis. All the successfully operated patients have done well and are now in functional Class I.

Of the 27 patients with aortic regurgitation, 7 had aortic valve replacements and I died in the post-operative period from septicaemia. All the survivors did well with reversion to functional Class I.

One patient died before an operation could be arranged. He was a man of 26 years, and though he had the largest regurgitant fraction of 86 per cent, he had negligible symptoms. An operation was advised because of gross and increasing cardiomegaly, extremely large enddiastolic volume and muscle mass, severe electrocardiographic abnormalities of left ventricular hypertrophy with $T$ wave inversion, and catheterization findings of severe aortic regurgitation. He declined an operation and died suddenly at home.

\section{Discussion}

Measurements of left ventricular volume parameters in various types of valvular disease have been reported by several investigators (Sandler et al., 1963; Hugenholtz and Wagner, 1970; Kennedy et al., 1966; Arvidsson and Karnell, 1964; Miller, Brown, and Swan, 1964; Jones et al., 1964; Miller, Kirklin, and Swan, 1965). Sandler et al. (1963) described their findings in a group of 37 patients with generally severe valve lesions of various types. Two patients with pure mitral regurgitation due to ruptured chordae tendineae were in heart failure and had regurgitant fractions of 75 and 77 per cent. Two patients with pure aortic regurgitation were described with regurgitant fractions of 77 and 30 per cent. Both were in heart failure, but the patient with the lower regurgitant fraction of 30 per cent had acute aortic regurgitation due to fenestration of a cusp.

Miller et al. (1964) reported 2 children with congenital mitral incompetence who had regurgitant fractions of 96 and 88 per cent and ejection fractions of 0.59 and 0.64 . Jones $e t$ al. (1964) reported volume measurements in a group of $8 \mathrm{I}$ adults with various valve lesions. Twenty-five patients with obvious mitral regurgitation had an average end-diastolic volume of $250 \mathrm{ml}$./patient (approximately 140 $\mathrm{ml} . / \mathrm{m}^{2}$ ) and an average regurgitant fraction of $6 \mathrm{I}$ per cent. Seventeen patients with obvious aortic regurgitation had an average enddiastolic volume of $293 \mathrm{ml}$./patient (approximately $160 \mathrm{ml} . / \mathrm{m}^{2}$ ) and an average regurgitant fraction of 58 per cent.
Dodge and Baxley (1969) reviewed volume data in 22 patients with aortic regurgitation who had a mean end-diastolic volume of $193 \pm 55.4 \mathrm{ml} . / \mathrm{m}^{2}$ and a mean ejection fraction of $0.56 \pm 0.13$. Their 29 patients with mitral regurgitation had a mean end-diastolic volume of $160 \pm 53 \mathrm{ml} . / \mathrm{m}^{2}$ and a mean ejection fraction of $0.47 \pm 0.10$.

Miller et al. (1965) studied I5 adults with mitral regurgitation and found regurgitant fractions from 44 to 87 per cent. All patients requiring operations at that time had a value of 58 per cent or higher. Some of their patients had mitral regurgitation due to ruptured chordae tendineae, and several of these had high or normal ejection fractions in spite of having symptoms. This may be related to the sudden onset of the lesion with a sudden rise in pulmonary venous pressure due to regurgitation into a small non-compliant atrium resulting in severe symptoms before any significant deterioration of myocardial function has occurred.

There is general agreement between these results and those reported here in that, in pure aortic or mitral regurgitation, a regurgitant fraction of over 60 per cent indicates a severe lesion. Almost all of the patients reported in these series who required an operation had regurgitant fractions in this range.

It appears that symptoms in mitral and aortic regurgitation may vary considerably according to the aetiology and speed of onset of the lesion. If, for example, there has been perforation of an aortic cusp or rupture of mitral chordae tendineae, acute regurgitation occurs into a relatively small, non-compliant chamber with a resultant rapid rise in pulmonary venous pressure and early onset of pulmonary oedema. Thus, the relation of left atrial size to symptoms in the mitral regurgitation group will reflect this variation. A high regurgitant fraction is only one of the elements contributing to left atrial size; duration of the regurgitation and wall compliance are other important features. As a consequence, size of the atrium cannot be taken as a reliable indicator of the severity of mitral regurgitation.

With long-standing congenital or rheumatic valvular insufficiency, the left ventricle and left atrium may dilate slowly without any conspicuous rise in pulmonary venous pressure. A progressively lower cardiac output and congestive heart failure without acute pulmonary oedema may then occur when the myocardium begins to fail. This stage may be detected by finding a reduced ejection fraction in the face of a normal or increased enddiastolic volume and/or a normal or decreased peripheral resistance. The mechanism 
responsible for producing this reduced contractility of the myocardium is uncertain. In the rheumatic group it is possible that the myocardium has been damaged at the time of the original episode of rheumatic carditis or that a rheumatic cardiomyopathy exists. Of the 2 I patients with mitral and aortic regurgitation who had an ejection fraction of 0.60 or less, only 4 were congenital, and 2 of these had received potassium citrate as a cardioplegic drug at a previous operation. The remaining 17 patients all had rheumatic heart disease. Fleming and Wood (1959) described the typical clinical profile of the middle-aged woman with a history of rheumatic fever, considerable cardiomegaly, atrial fibrillation, obvious symptoms, and yet only mild mitral valve lesions found at operation or necropsy. They pointed out that a myocardial factor was present in some patients with rheumatic heart disease and should be recognized. The findings of the present study are in keeping with this concept. Other possible causes of a low ejection fraction include myocardial anoxia due to poor myocardial perfusion, acidosis, and catecholamine depletion (Chidsey et al., 1966), all of which may be present in long-standing severe valve disease (Chidsey, Harrison, and Braunwald, 1962; Chidsey, Braunwald, and Morrow, 1965).

Three of the patients studied here died in the post-operative period. Two of these died from infection and one, who had an ejection fraction of 0.39 , died on the first post-operative day after atelectasis. One other patient with mitral regurgitation had an even lower ejection fraction of 0.34 , yet survived operation and is doing well 3 years after valve replacement. Therefore, a low ejection fraction should not be an absolute contraindication to valve operation, but the presence of a low ejection fraction without a large regurgitant fraction suggests that the valve lesion is relatively mild, and raises the suspicion of a more significant myocardial disorder. It is felt that long-term follow-up will be necessary to assess the prognostic significance of a depressed ejection fraction.

Urschel et al. (1968) have shown that the acute production of mitral or aortic insufficiency causes an increase in ejection fraction due to the sudden decrease in the impedance to ejection, the afterload. Thus, a 'normal' ejection fraction in a patient with a regurgitant lesion and a healthy myocardium may well be above 60 per cent, which we selected as a lower normal limit for the age-group studied. Furthermore, recent studies from this laboratory have shown that a 'normal' ejection fraction may persist even when force-velocity parameters suggest depressed myocardial contractility. While a low ejection fraction probably correctly denotes a depressed myocardium, a 'normal' ejection fraction in a regurgitant lesion does not necessarily mean that the myocardium is normal.

It is perhaps surprising that large volumes were tolerated less well in our patients with mitral regurgitation than in those with aortic regurgitation. Braunwald (1969) has pointed out that mitral regurgitation is usually better tolerated than aortic regurgitation because of the lower wall stress required to eject blood into the low resistance left atrium. However, it will be noted that all of our patients with mitral regurgitation in Class III or IV had rheumatic disease, and undoubtedly a myocardial factor contributed to their severe symptoms.

\section{References}

Arvidsson, H., and Karnell, J. (1964). Quantitative assessment of mitral and aortic insufficiency by angiocardiography. Acta Radiologica Diagnosis, 2, I05.

Braunwald, E. (1969). Mitral regurgitation: physiologic, clinical and surgical considerations. New England fournal of Medicine, 281, 425.

Chidsey, C. A., Braunwald, E., and Morrow, A. G. (1965). Catecholamine excretion and cardiac stores of norepinephrine in congestive heart failure. American fournal of Medicine, 39, 442.

$\longrightarrow$, Harrison, D. C., and Braunwald, E. (I962). Augmentation of the plasma nor-epinephrine response to exercise in patients with congestive heart failure. New England fournal of Medicine, 267, 650 .

$\longrightarrow$, Sonnenblick, E. H., Morrow, A. G., and Braunwald, E. (1966). Norepinephrine stores and contractile force of papillary muscle from the failing human heart. Circulation, 33, 43.

Dodge, H. T., and Baxley, W. A. (1969). Left ventricular volume and mass and their significance in heart disease. American fournal of Cardiology, 23, 528.

, Sandler, H., Ballew, D. W., and Lord, J. D. (1960). The use of biplane angiocardiography for the measurement of left ventricular volume in man. American Heart fournal, 60, 762.

Fleming, H. A., and Wood, P. (1959). The myocardial factor in mitral valve disease. British Heart fournal, 21, 117 .

Hugenholtz, P. G., and Wagner, H. R. (I970). Assessment of myocardial function in congenital heart disease. In Pathophysiology of Congenital Heart Disease, pp. 20I-23r. Ed. by F. H. Adams, H. J. G. Swan, and V. E. Hall. UCLA Press (UCLA Forum Med. Sci. No. IO), Los Angeles.

Jones, J. W., Rackley, C. E., Bruce, R. A., Dodge, H. T., Cobb, L. A., and Sandler, H. (1964). Left ventricular volumes in valvular heart disease. Circulation, 29, 887.

Kennedy, J. W., Baxley, W. A., Figley, M. M., Dodge, H. T., and Blackmon, J. R. (I966). Quantitative angiocardiography. I. The normal left ventricle in man. Circulation, 34, 272.

Miller, G. A. H., Brown, R., and Swan, H. J. C. (1964). Isolated congenital mitral insufficiency with particular reference to left heart volumes. Circulation, 29, 356. 
_, Kirklin, J. W., and Swan, H. J. C. (1965). Myocardial function and left ventricular volumes in acquired valvular insufficiency. Circulation, 31, 374.

Rackley, C. E., Dodge, H. T., Coble, Y. D., and Hay, R. E. (1964). A method for determining left ventricular mass in man. Circulation, 29, 666.

Sandler, H., Dodge, H. T., Hay, R. E., and Rackley, C. E. (1963). Quantitation of valvular insufficiency in man by angiocardiography. American Heart fournal, 65, 501.

Urschel, C. W., Covell, J. W., Sonnenblick, E. H., Ross, J., Jr., and Braunwald, E. (I968). Myocardial mechanics in aortic and mitral valvular regurgitation: the concept of instantaneous impedance as a determinant of the performance of the intact heart. fournal of Clinical Investigation, 47, 867. 